Jonas Elias Castro da Rocha', Alberto Bentes Brasil Neto', Norberto Cornejo Noronha', Marcos André Piedade Gama', Eduardo Jorge Macklouf Carvalho², Arystides Resende Silva², Cassio Rafael Costa Dos Santos ${ }^{1+}$

\title{
ORGANIC MATTER AND PHYSICAL-HYDRIC QUALITY OF AN OXISOL UNDER EUCALYPT PLANTING AND ABANDONED PASTURE
}

Keywords:

Forestry plantation

Degraded pastures

Amazon

Soil physics

Soil water infiltration

Retention

Histórico:

Recebido 29/08/2016

Aceito 17/11/2016

Palavras chave: Plantação florestal Pastagens degradadas Amazônia

Física do solo

Retenção e infiltração de água no solo

Correspondência: rafaelsantos.18@hotmail.com
ABSTRACT: The aim of this study was to assess organic matter and physical-hydric attributes of an Oxisol under a clonal planting of eucalypt and an abandoned pasture in comparison to a successional forest with its soil under natural conditions at Paragominas municipality, southeast region of the state of Pará. In July 2013, soil samples were collected at the depths $0-0.15$ and $0.15-0.35 \mathrm{~m}$, which were used for the determination of the following attributes: organic matter content; soil bulk density; porosity, soil water retention and $S$ index. In field, soil water infiltration tests were performed. The abandoned pasture was the system that presented the greatest contents of organic matter in the soil surface, when compared to successional forest and eucalypt clonal plantation. None of the studied systems achieved a critical level for bulk density and $\mathrm{S}$ index values and all systems had water infiltration speed classified as very high. Based on these variables, the soil management with eucalypt cultivation with two years of implantation may be recommended in areas with abandoned pastures.

\section{MATÉRIA ORGÂNICA E QUALIDADE FÍSICO-HÍDRICA DE UM LATOSSOLO SOB PLANTIO DE EUCALIPTO E PASTAGEM ABANDONADA}

RESUMO: O objetivo deste estudo foi avaliar a matéria orgânica e atributos físico-hídricos de um Latossolo sob um plantio clonal de eucalipto e uma área de pastagem abandonada em comparação a uma floresta sucessional com suas condições edáficas naturais no município de Paragominas, região sudeste do Estado do Pará. Em julho de 2013, amostras de solo foram coletadas às profundidades $0-0,15$ e $0,15-0,35 \mathrm{~m}$, as quais foram utilizadas para a determinação dos seguintes atributos: teor de matéria orgânica, densidade, porosidade, curva de retenção de água e índice S. Em campo, testes de infiltração de água no solo foram realizados. A pastagem abandonada foi o sistema que apresentou os maiores teores de matéria orgânica na superfície do solo, quando comparado à floresta sucessional e ao plantio clonal de eucalipto. Nenhum dos sistemas estudados obtiveram um nível crítico para os valores de densidade do solo e índice $\mathrm{S}$ e todos os sistemas apresentaram uma velocidade de infiltração básica de água classificada como muito alta. Com base em tais variáveis, o manejo do solo com cultivo de eucalipto com dois anos de implantação pode ser recomendado em áreas com pastagens abandonadas.

' Federal Rural University of Amazon - Paragominas, Pará, Brasil

2 Embrapa Eastern Amazon - Belém, Pará, Brazil 


\section{INTRODUCTION}

The large international demand for woody products and the strong pressure for the conservation of remaining native forests in the Amazon has favored the installation of planted forests in the region, especially in areas already deforested and with evidence of soil degradation (FARIAS et al., 20I6). Besides the production of raw material for energy, timber and cellulose, forestry plantations can also be used for rehabilitation of degraded ecosystems and for the services of environmental compensation at altered areas (ALMEIDA et al., 20 I I).

In the Southeast of Pará state, forest planting with species from the Eucalyptus genus are in ample expansion, many times in areas with pastures. These areas often have soils with low fertility, erosive processes and elevated degree of compaction. In this context, it is believed that such plantations could be quite efficient in the rehabilitation of degraded areas, because the large plasticity and adaptability of the tree individuals to many edaphic and environmental conditions, which allows them to ensure the soil protection and productivity instead of the abandoned areas during long periods of fallow trying to reestablishing its productivity (VIANA, 2004).

In order to know the effects of planted forest stands on the edaphic attributes of Amazon soils, it is possible to resort to some variables such as soil organic matter, physical and hydric variables, which has been efficacious in the inference of soil quality (REICHERT et al., 2009; MONCADA et al. 20I4). However, most studies developed with Eucalyptus species in the Amazon normally cover the production (ARCO-VERDE; SCHWENGBER, 2003), mineral nutrition (MATOS et al., 20I2), handling and propagation (TEIXEIRA, 20I3), timber quality (ARAUJO et al., 20I2), and entomofauna (BORGES, 20II). Nevertheless, studies that aim to investigate the effect of these plantations on organic matter content and soil physical quality are still incipient.

According to Reynolds et al. (2002), a soil with suitable physical conditions often shows a structure that facilitates root growth and maintenance, edaphic fauna proliferation, compaction reduction, movement and storage of air, water and nutrients. Therefore, physical attributes such as bulk density, porosity, water infiltration and retention, as well as organic matter, are convenient for use in the investigation of alterations of soil quality (REICHERT et al., 2007).

Another important tool to evaluate the soil physical and structural quality is the $S$ index proposed by Dexter (2004) and adjusted through soil retention curves. Obtained from the inflexion point of the retention curve, $\mathrm{S}$ index is a direct reflex of the soil pores size distribution and is very useful in comparing different management systems and to recognize the soil physical quality (TORRES et al., 20I4).

Under the hypothesis that organic matter and physical-hydric quality of a soil from an area of abandoned pasture can be potentiated with an eucalypt clonal planting, taking as reference a fragment of adjacent successional forest, the aim of this study was to evaluate the organic matter and some physical-hydric attributes of an Oxisol under clonal planting of eucalypt, abandoned pasture and successional forest, in Paragominas municipality, Southeast of Pará state.

\section{MATERIALS AND METHODS}

The present study was carried out in three adjacent areas, which are located at the following coordinates: $3^{\circ} 08^{\prime} \mathrm{II}$ " and $3^{\circ} 08^{\prime} 68^{\prime \prime}$ of South latitude and 47'16'58" and 47'17'40" of West longitude, in Paragominas municipality, belonging to Southeast of Pará state. This municipality presents a climate classified as Aw, according to Köppen classification system, with an expressive dry season, annual average temperature of $25^{\circ} \mathrm{C}$, precipitation between 2,250 and $2,500 \mathrm{~mm}$ and relative air moisture of $85 \%$ (SEPOF, 2014).

The soil from the study area is classified as a Loam-textured Oxisol and is located in an undulated relief. The following management systems (treatments) were assessed: pasture with grass from the Brachiaria sp genus in a fallow of 4 years (PAS); commercial planting of eucalypt clones (EUC); and a successional forest remnant (FFS). Previously, the systems PAS and EUC consisted of pasture until the year of 2009, when this area went fallow until $201 \mathrm{I}$. From then on, a part of this area was intended to clonal planting of eucalypt (EUC) and the other part of the area remained in fallow (PAS).

The preparing of the area for eucalypt implantation occurred with a mechanized application of I,200 kg.ha-1 of lime and with a mechanized subsoiling until the depth of $60 \mathrm{~cm}$ while an application of $450 \mathrm{~kg} \cdot \mathrm{ha}^{-1}$ of reactive natural phosphate was performed at the same time. The plantation was carried out in a spacing of $3 \times 3 \mathrm{~m}$. Then, $150 \mathrm{~kg} \cdot \mathrm{ha}^{-1}$ of NPK fertilizer at the concentration of $06-30-06+$ micronutrients $(0.5 \%$ of $B+0.3 \%$ of $\mathrm{Zn}+0.3 \%$ of $\mathrm{Cu}$ ) were applied in lateral pits beside the plants. Furthermore, three top dress fertilizations were made, at 3, 12 and 24 months after planting, with a total application of $500 \mathrm{~kg} \cdot \mathrm{ha}^{-1}$ of NPK fertilizer with the formulation 15-00-30+ micronutrients. Such NPK and micronutrients concentration was determined based 
on the nutritional balance between the soil chemical attributes and the supplementation by the program of fertilization adopted in the area.

In July 20I3, on each system, ten plots with 300 $\mathrm{m}^{2}(30 \times 10 \mathrm{~m})$ were stablished randomly, in which soil sampling with deformed and undeformed structure were made on the soil surface $(0-0.15 \mathrm{~m})$ and on subsurface $(0.15-0.35 \mathrm{~m})$ totaling 20 deformed samples and 20 undeformed samples for each system. Field tests with soil water infiltration were also performed. In EUC, the sampling was done in the eucalypt planting row.

The deformed samples were obtained in order to characterize soil chemical (total nitrogen, organic matter, $\mathrm{pH}$, phosphorus, potassium, calcium, magnesium and aluminum) and physical attributes (particle density and granulometry) (Table I).The methods used for chemical characterization and for determination of particles density and granulometry are described in Embrapa (1997).

With the deformed samples, the soil organic matter content (OM) was also determined in each system, through the determination of organic carbon according to the method described by Embrapa (1997). With the organic carbon content, the organic matter was calculated by $[\mathrm{I}]$ :

$\mathrm{OM}\left(\mathrm{g} \cdot \mathrm{kg}^{-1}\right)=\mathrm{C} . \mathrm{org}\left(\mathrm{g} \cdot \mathrm{kg}^{-1}\right) \cdot 1.724$

Soil undeformed samples were obtained with volumetric rings of $100 \mathrm{~cm}^{3}$, which were used to obtain the following variables: soil bulk density (SD), total porosity (TP), macro porosity (Ma) and microporosity (Mi), pores diameter and soil water retention. Soil bulk density (SD) was determined by the volumetric ring method. Total porosity (TP) was calculated by the equation $T P=((I-S D)$. $\left.(P D)^{-1}\right)$. The macro porosity was obtained by the soil water retention curve at a tension correspondent to $6 \mathrm{kPa}$. The macro porosity was determined by the difference between total and micro porosity.

The soil water infiltration was assessed by the method of concentric rings, which were composed by a larger metallic ring, with $25 \mathrm{~cm}$ of height and $20 \mathrm{~cm}$ of diameter and a smaller ring with $25 \mathrm{~cm}$ of height and $10 \mathrm{~cm}$ of diameter. Both rings were inserted on soil surface concentrically, with 10 replications for each system. With these data, the cumulative infiltration $(\mathrm{Cl})$ was determined, which corresponds to the function between the water blade infiltrated and accumulated on the soil and the corresponding time $(T)$. Through $\mathrm{Cl}$, the parameters " $k$ " and "a" were determined from the nonlinear regression proposed by Kostiakov ( 1932) [2]:

$\mathrm{Cl}=\mathrm{kTa}$

With the derivation of infiltration function by time, it is possible to find the potential model of soil water infiltration speed (IS) [3]:

$\mathrm{IS}=\frac{\mathrm{dIA}}{\mathrm{dT}}=\mathrm{k}$ a Ta

After curve fitting, the last value of IS obtained after its stability was considered the soil water basic infiltration speed (BIS), which was taken from the IS curves of each system.

The water retention at tensions $0,10,30,100$, $500,1,000$ and I,500 kPa were determined with soil samples previously saturated with water on a porous ceramic plate through application of the tensions. Pores volume distribution was calculated by the following manner: I - pores $\geq 50 \mu \mathrm{m}$ - by the difference among the value of total porosity and the volumetric moisture obtained at the pressure $6 \mathrm{kPa}$; II - pores between 50 $\mu \mathrm{m}$ and $30 \mu \mathrm{m}$ - difference of volumetric moistures between 6 and $10 \mathrm{kPa}$; III - pores between $30 \mu \mathrm{m}$ and $10 \mu \mathrm{m}$ - difference of volumetric moistures between 10 and $30 \mathrm{kPa}$; IV - pores between $10 \mu \mathrm{m}$ and $3 \mu \mathrm{m}$ difference of volumetric moistures between 30 and 100 $\mathrm{kPa}$; $\mathrm{V}$ - pores between $3 \mu \mathrm{m}$ and $0.2 \mu \mathrm{m}$ - difference of volumetric moistures between 100 and I,500 kPa; VI - pores $\leq 0.2 \mu \mathrm{m}$ - value of volumetric moisture at the pressure of $\mathrm{I}, 500 \mathrm{kPa}$.

TABLE I Chemical attributes, particles density and granulometry of an Oxisol under abandoned pasture (PAS), clonal planting of eucalypt (EUC) and successional forest (FFS).

\begin{tabular}{|c|c|c|c|c|c|c|c|c|c|c|c|}
\hline \multirow{2}{*}{ System } & $\mathrm{pH}$ & $\mathrm{P}$ & $\mathrm{K}$ & $\mathrm{Ca}$ & $\mathrm{Mg}$ & $\mathrm{Al}$ & BS & PD & Sand & Silt & Clay \\
\hline & $\left(\mathrm{H}_{2} \mathrm{O}\right)$ & $\left(\mathrm{mg} \cdot \mathrm{dm}^{-3}\right)$ & ---------- & ------ & $\mathrm{nol}_{\mathrm{c}} \cdot \mathrm{dm}$ & --- & ------ & $\mathrm{kg} \cdot \mathrm{dm}^{-3}$ & \multicolumn{3}{|c|}{ 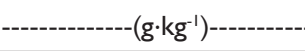 } \\
\hline & & & & & --0 & . & 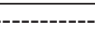 & 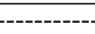 & --- & ---- & $-\cdots$ \\
\hline PAS & 5.35 & 5.5 & 0.09 & 1.05 & 0.8 & 0.90 & 1.94 & 2.60 & 44 & 385 & 527 \\
\hline EUC & 5.6 & 18.5 & 0.10 & 2.0 & 1.10 & 0.30 & 3.20 & 2.60 & 35 & 384 & 547 \\
\hline \multirow[t]{2}{*}{ FFS } & 5.65 & 5.0 & 0.13 & 1.20 & 2.55 & 0.15 & 3.88 & 2.58 & 52 & 363 & 533 \\
\hline & & & & & ---0. & $35 \mathrm{~m}-$ & & & & & \\
\hline PAS & 5.6 & 7.0 & 0.06 & 1.20 & 0.70 & 0.55 & 1.96 & 2.57 & 19 & 262 & 700 \\
\hline EUC & 5.7 & 14.0 & 0.06 & 1.55 & 1.49 & 0.30 & 2.51 & 2.58 & 19 & 268 & 693 \\
\hline FFS & 5.25 & 3.0 & 0.04 & 0.85 & 0.60 & 0.80 & 1.49 & 2.55 & 67 & 165 & 700 \\
\hline
\end{tabular}

P - phosphorus; K -potassium; Ca -calcium; Mg -magnesium; Al - aluminum; BS-bases sum; PD - particle density. 
With the points $\theta$ and $\Psi_{m}$ determined, the fit of the water retention curves was performed according to the model exposed by Van Genuchten (1980) [4], Where: $\theta=$ soil moisture $\left(\mathrm{cm}^{3} \cdot \mathrm{cm}^{-3}\right) ; \theta r=$ residual volumetric moisture $\left(\mathrm{cm}^{3} \cdot \mathrm{cm}^{-3}\right) ; \theta \mathrm{s}=$ saturated volumetric moisture $\left(\mathrm{cm}^{3} \cdot \mathrm{cm}^{-3}\right)$; $\Psi$ mat $=$ matric potential $(\mathrm{kPa}) ; 0, \mathrm{n}$ and $\mathrm{m}=$ equation empirical parameters.

$$
\theta=\theta r+\frac{\theta s-\theta r}{\left[1+(a|\Psi m a t|)^{n}\right]^{m}}
$$

This fit was done by the method that takes into account $=$ max, with $\mathrm{m}=0$ and $=$ min, withm = I,500 kPa. With the parameters that were fitted from the Van Genuchten model, the $S$ index was calculated in accordance to Dexter (2004) [5]:

$S=-n(\theta s-\theta r)\left[1+\frac{1}{m}\right]^{-[1+m]}$

The data obtained were submitted to analysis of variance (ANOVA) and to Scott-Knott test for discriminations of treatments means, at $5 \%$ significance.

\section{RESULTS AND DISCUSSION}

At Table 2 we can find the results regarding to organic matter, bulk density, total porosity, macro porosity and micro porosity. At the surface layer (0-0.15 $\mathrm{m})$, the organic matter content was significantly greater in PAS in comparison to EUC and FFS. This result can be explained by the predominance of grasses in the previous system. These grasses often present an extensive root system and an elevated root renewal rate (PEREIRA et al., 2009), which may provide incorporation of organic matter directly on the surface layer of the soil profile, differently of what occurs in a natural forest, in which the source of soil organic matter depends on litter fall. These results with larger values of OM in abandoned pasture areas in comparison to forestry fragments in the Amazon were also found by Silva et al. (2006).

In turn, the smallest amount of soil organic matter found in EUC when compared to PAS may be explained by the soil preparation with subsoiling, that normally furthers a larger rate of oxidation of organic matter and destroys soil aggregates, as well as providing bigger soil exposure to climatic factors (BAYER; MIELNICZUK, 2008). This process can result in lower replenishment of the organic matter on the soil profile, since in forest plantations, in which weed competition is periodically controlled, the increase of soil organic matter depends fundamentally on the litter fall which is deposited by the trees.
TABLE 2 Organic matter (OM), soil bulk density (SD), total porosity (TP), macroporosity (Ma) and microporosity (Mi) of an Oxisol under abandoned pasture (PAS), plantation of clonal eucalypt (EUC) and successional forest (FFS).

\begin{tabular}{|c|c|c|c|c|c|c|}
\hline \multirow{2}{*}{ System } & Depth & OM & SD & TP & $\mathrm{Ma}$ & Mi \\
\hline & $\mathrm{m}$ & $\mathrm{g} \cdot \mathrm{kg}^{-1}$ & $\mathrm{~kg} \cdot \mathrm{dm}^{-3}$ & \multicolumn{3}{|c|}{ - } \\
\hline PAS & & $44.57^{\mathrm{a}}$ & $1.25^{\mathrm{b}}$ & $0.5 \mathrm{I}^{\mathrm{b}}$ & $0.22^{\mathrm{b}}$ & 0.29 \\
\hline EUC & $0-0.5$ & $26.97^{b}$ & $1.37^{\mathrm{a}}$ & $0.48^{c}$ & $0.19^{b}$ & 0.30 \\
\hline FFS & & $30.74^{b}$ & $1.09^{c}$ & $0.57^{\mathrm{a}}$ & $0.30^{\mathrm{a}}$ & 0.28 \\
\hline F Test & & $6.65^{* *}$ & $22.74^{* *}$ & $22.86^{* *}$ & $|1.7|^{\circ *}$ & $1.57 \mathrm{~ns}$ \\
\hline CV\% & & 33.3 & 7.7 & 6.66 & 24.86 & 11.28 \\
\hline PAS & & $21.36^{\mathrm{b}}$ & 1.31 & 0.49 & 0.16 & $0.33^{\mathrm{a}}$ \\
\hline EUC & $0.15-0.35$ & $17.99^{b}$ & 1.35 & 0.48 & 0.18 & $0.30^{\mathrm{b}}$ \\
\hline FFS & & $26.48^{\mathrm{a}}$ & 1.27 & 0.50 & 0.21 & $0.29^{b}$ \\
\hline F Test & & $3.40^{\circ}$ & $1.86^{\mathrm{ns}}$ & $1.08^{\mathrm{ns}}$ & $1.40^{\mathrm{ns}}$ & $10.57^{* *}$ \\
\hline CV\% & & 33.5 & 6.83 & 7.92 & 32.84 & 8.86 \\
\hline
\end{tabular}

The means followed by equal letters in the columns do not differ statistically among each other according to the Scott Knott test (5 \% significance). **, *, ns: significant at I \%, $5 \%$, and non-significant, respectively.

The values of bulk density varied from 1.09 to $1.37 \mathrm{~kg} \cdot \mathrm{dm}^{-3}$ and they are below the critical limit for root development that was stablished by Reichert et al. (2003), corresponding to $1.55 \mathrm{~kg} \cdot \mathrm{dm}^{-3}$ for soils with clay content between 200 and $550 \mathrm{~g} \cdot \mathrm{kg}^{-1}$, and to $1.45 \mathrm{~kg} \cdot \mathrm{dm}^{-3}$ for soil with clay content higher than $550 \mathrm{~g}^{\mathrm{kg}} \mathrm{kg}^{-1}$, indicating that the abandoned pasture or the soil management with eucalypt planting do not offer physical limitations to plant development regarding bulk density.

Significant differences in soil bulk density for studied systems were observed only on surface and EUC showed the biggest values for this variable followed by the PAS system and these two systems were superior to FFS with regard to this variable. Guariz et al. (2009) studied an Oxisol and also found that the soil under eucalypt cultivation and abandoned pasture had bigger bulk density in comparison to a soil under natural vegetation. These authors supported that such factors are due to the densification of surface layers through the larger exposure to climatic factors, such as the impact of raindrop as well as the compaction provided by the trampling of animals in the pastures and the use of machinerie for implantation and maintenance of the tree stand.

On the subsurface $(0.15-0.35 \mathrm{~m})$, all systems were equal with regard to bulk density, pointing that the soil management under pasture and clonal eucalypt stand did not promote, until the moment of data sampling, significant enough changes to differentiate the soil bulk density of these areas to the natural conditions found in FFS in this soil layer.

The results of total porosity also evidence that there were statistical differences among the systems 
only on surface layer. In a joint analysis with the bulk density, we can observe that, on surface, the remnant of successional forest presented the best physical condition, probably due to the lower anthropic interference and the higher conservation of the system natural dynamics.

The increase of organic matter content on soil surface, which normally favors biological activity and soil aggregation, could probably influenced the decrease of bulk density and increase of total porosity of soil under PAS in relation to EUC. It is important to highlight the influence of subsoiling operation on the area submitted to eucalypt cultivation, which often provides the reduction of soil bulk density and increase of porosity. However, the soil tillage generally promotes the destabilization on its structure due to the particles dispersion and reorganization, that favors their packing resulting on the increase of bulk density and the reducing of total porosity in the first years after the operation (SILVA et al., 20I2).

Referent to macro porosity, PAS and EUC did not differ between each other on surface and were significantly lower than FFS in this layer (Table 2 and diameter class $\geq 50 \mu \mathrm{m}$, Figure IA). These results are due to the soil tillage system with animal trampling, use of machinery and soil preparing operations, which foment alterations on these pores, reflecting directly on soil water infiltration (Figure 2), since the macro pores are known to be the main determinant factor on soil water movement and behavior (REICHART et al., 2007).

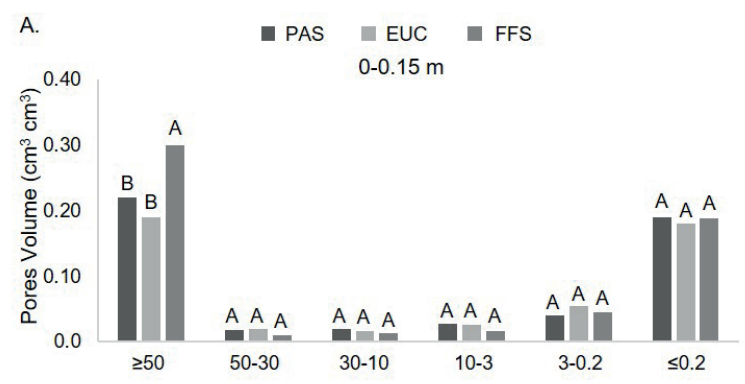

B.

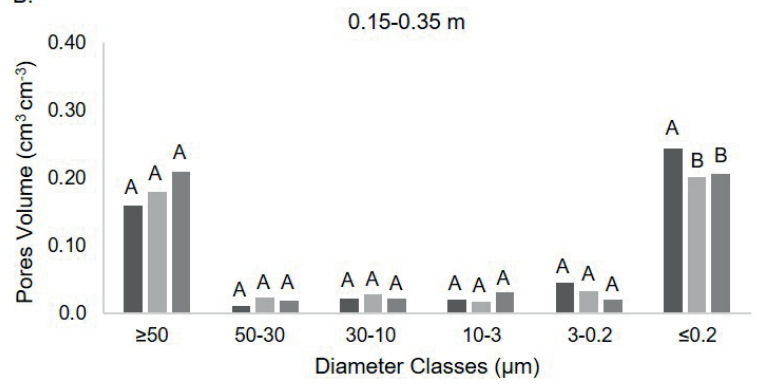

FIGURE I Distribution of pores diameter volume (A and B) of an Oxisol under abandoned pasture (PAS), clonal eucalypt plantation (EUC) and successional forest (FFS). Equal letters for diameters classes at $\mathrm{A}$ and $B$ do not differ among each other according to the Scott Knott at $5 \%$ of significance.
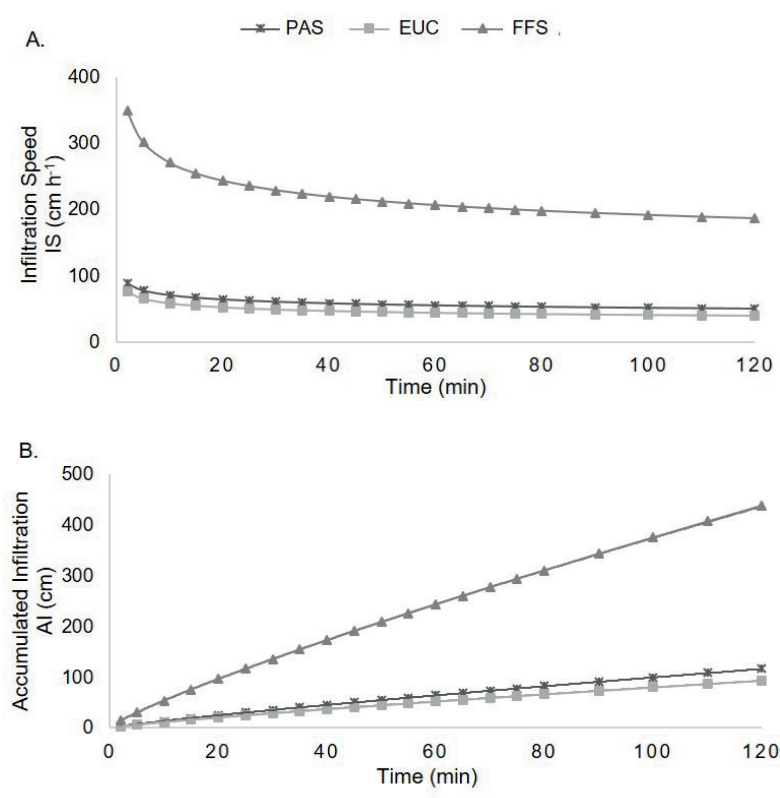

FIGURE 2 Curves of accumulated infiltration and infiltration speed of soil water (A and B) of an Oxisol under abandoned pasture (PAS), clonal eucalypt plantation (EUC) and successional forest (FFS).

In Table 3 are presented the mean values and coefficient of variation (CV) for soil water infiltration speed (IS) as well as equations with their respective coefficients. The IS values were classified as very high $\left(\mathrm{VIB}>3 \mathrm{~cm} \cdot \mathrm{h}^{-1}\right)$ in agreement with classification proposed by Bernardo et al. (2006). High values of BIS point that the drainage on these systems is adequate, which reduces erosive processes, very common in the Pará southeast region due to the occurrence of a softly corrugated and corrugated relief and inadequate tillage practices.

On the other hand, even with the intense usage of machinery and maintenance practices, BIS for the eucalypt clonal planting remained elevated. This indicates the efficiency of such system by proportionating a high infiltration, due to the fact that this process decreases the intensity of surface runoff and erosive processes.

TABLE 3 Average values and coefficient of variation (CV) for soil water infiltration speed (IS) followed by equations and coefficients from the fit of the water infiltration speed in an Oxisol under abandoned pasture (PAS), clonal eucalypt plantation (EUC) and successional forest (FFS).

\begin{tabular}{ccccc}
\hline Systems & IS $\left(\mathrm{cm} \cdot \mathrm{h}^{-1}\right)$ & $\begin{array}{c}\mathrm{CV} \\
(\%)\end{array}$ & $\begin{array}{c}\text { Water Infiltration } \\
\text { Speed }\end{array}$ & $\mathrm{R}^{2}$ \\
\hline PAS & $50.33^{\mathrm{b}}$ & 21.3 & $\mathrm{IS}=97,435 \mathrm{~T}-0,138$ & 0.999 \\
EUC & $39.58^{\mathrm{b}}$ & 23.3 & $\mathrm{IS}=84, \mathrm{I} 55 \mathrm{~T}-0,159$ & 0.994 \\
FFS & $186.28^{\mathrm{a}}$ & $28 . \mathrm{I}$ & $\mathrm{IS}=385,69 \mathrm{~T}-0,153$ & 0.997 \\
F Test & $27.55^{* *}$ & - & - & - \\
\hline
\end{tabular}

Means followed by equal letters in the columns do not differ statistically according to the Scott Knott test (5 \% of significance). (**) significant at I\%. 
No differences were observed for IS among PAS and EUC, but these systems were significantly lower than FFS. These results can be pointed as direct reflexes of alterations of soil structure. In addition to the larger volume of macro pores in FFS, it is valid to consider the common presence of pores from biological source due to the decomposition of roots and/or edaphic fauna activity in surface layer of these environments, which influence directly the soil water infiltration because of the easy drainage and water movement occasioned by the gravity action in these pores (REICHART et al., 2003).

Souza et al. (20II) also found very high BIS values in a Yellow Oxisol in the state of Pará, which ranged from 90.42 to $169.71 \mathrm{~cm} \cdot \mathrm{h}^{-1}$, and this last value was obtained in a secondary forest with a fallow of 20 years. Furthermore, these authors observed a great reduction in water infiltration with the conversion of the forest into successional agroforestry systems when compared to a successional forest of 20 years and they attribute such result to the process of soil compaction provided by its tillage.

The parameters $(\alpha, m, n, \theta r$ and $\theta s)$ referent to the Van Genuchten (1980) model, the coefficient of determination $\left(R^{2}\right)$ and the $S$ index relative of different systems and depths are presented in Table 4. The soil water retention curves are presented in Figure 2. The Van Genuchten model was efficient to describe the retention curves, with high coefficients of determination $\left(R^{2}>0.980\right)$ (Figure $2 A$ and $2 B$ ).

Taking into account the limits of the $S$ Indexproposed by Dexter (2004) ( $\mathrm{S} \geq 0.050$ very good; $0.050>S \geq 0.035$ good; $0.035>S \geq 0.020$ poor and $0.020>S$ very poor) values higher than 0.035 were observed in all systems and depths, which is suggested as the limit between soils with suitable and poor structural quality.

The results of $S$ Index indicate that a great amount of pores drain water at the point of inflexion. This was highlighted by the elevated infiltration speed found in the studied systems. In PAS, the lowest values of S Index were

TABLE 4 Parameters referent to the Van Genuchten model in an Oxisol under abandoned pasture (PAS), clonal eucalypt plantation (EUC) and successional forest (FFS) at different depths, using the method in which the extreme values of soil moisture were fixed at: $\theta \mathrm{s}=\theta \max$ and $\theta \mathrm{r}=\theta \mathrm{min}$, with $\mathrm{n}$ dependent on $\mathrm{m}$.

\begin{tabular}{|c|c|c|c|c|c|c|c|c|}
\hline \multirow[b]{2}{*}{ System } & \multirow{2}{*}{$\begin{array}{c}\text { Depths } \\
\text { (m) }\end{array}$} & \multicolumn{6}{|c|}{ Parameters of the Van Genuchten equation } & \multirow[b]{2}{*}{ S Index } \\
\hline & & $\begin{array}{c}\mathrm{A} \\
\left(1 \cdot \mathrm{cm}^{-1}\right)\end{array}$ & $\mathrm{m}$ & $\mathrm{n}$ & $\begin{array}{c}\theta r \\
---\left(m^{3}\right.\end{array}$ & $\begin{array}{c}\theta s \\
\left.m^{-3}\right)--\end{array}$ & $\mathrm{R}^{2}$ & \\
\hline PAS & & $4.75 I$ & 0.237 & 1.310 & 0.189 & 0.444 & 0.989 & 0.043 \\
\hline EUC & $0-0.15$ & 1.537 & 0.251 & 1.335 & 0.181 & 0.436 & 0.985 & 0.046 \\
\hline FFS & & 1.167 & 0.330 & 1.492 & 0.190 & 0.420 & 0.997 & 0.054 \\
\hline PAS & & 2.438 & 0.254 & 1.341 & 0.244 & 0.485 & 0.991 & 0.044 \\
\hline EUC & & 1.090 & 0.324 & 1.479 & 0.201 & 0.45 & 0.998 & 0.057 \\
\hline FFS & & 0.810 & 0.400 & 1.665 & 0.206 & 0.433 & 0.996 & 0.065 \\
\hline
\end{tabular}

observed, especially on subsurface. This can be associated with the greater quantity of pores with smaller diameters which decrease the inclination of the water retention curve (DEXTER, 2004; TORRES et al., 20I4).
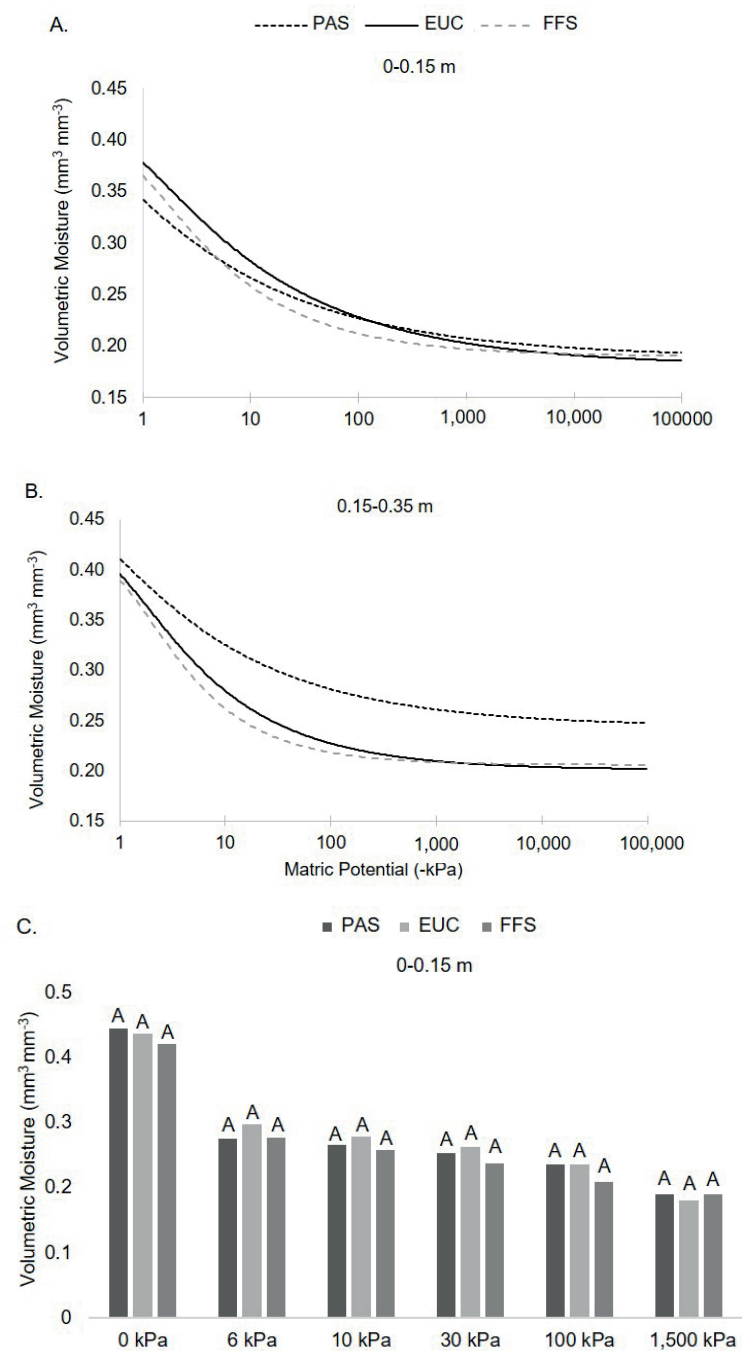

D.

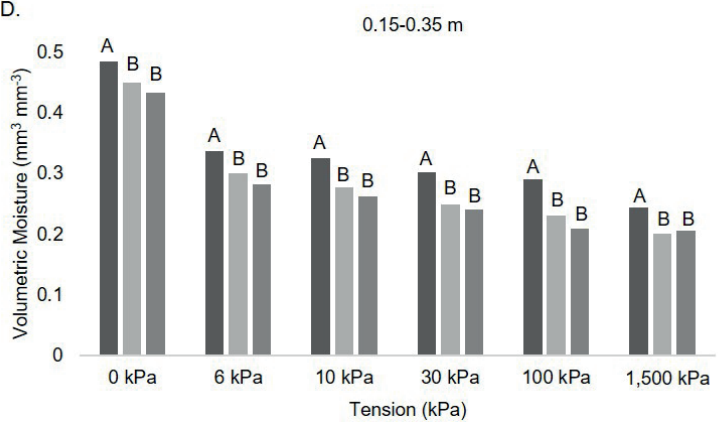

FIGURE 3 Soil water retention curve estimated by the Van Genuchten equation (A and B) and water content at tensions $0,6,10,30,100$ and $1,500 \mathrm{kPa}(\mathrm{C}$ and D) of an Oxisol under abandoned pasture (PAS), clonal eucalypt plantation (EUC) and successional forest (FFS). *Equal letters do not differ statistically according to the Scott Knott test (5\% significance). 
In the zone of matric potential between 10 and $\mathrm{I}, 500 \mathrm{kPa}$, there were no significant differences among systems on the surface. Notwithstanding, the system with abandoned pasture presented values of soil water retention significantly larger for all classes of tension analyzed on the subsurface. This behavior is associated the greater amount of pores of smaller diameter, which reduces the inclination of the water retention curve.

Based on the values of soil bulk density, BIS and $S$ Index, it was observed that soil management with eucalyptus keeps the soil in a range considered as suitable for these variables. This indicates that this system is efficient in conditioning the soil with proper physical conditions.

\section{CONCLUSIONS}

The abandoned pasture had the largest content of soil organic matter on the surface when compared to the remnant of successional forest and clonal eucalypt plantation.

With respect to soil organic matter and physical attributes soil bulk density, total porosity, and macro porosity, the system of eucalypt cultivation with two years of implantation and abandoned pasture were different to the fragment of successional forest only on the surface layer.

None of the studied systems reached a critical level for values of soil bulk density and $S$ Index, in addition to that all systems presented an infiltration speed classified as very high. Based on these variables, the soil tillage with clonal eucalypt plantations with two years of implantation may be recommended for areas occupied with abandoned pasture.

\section{REFERENCES}

ALMEIDA, L. S. de; COUTINHO, C. H. O.; SANTANA, A. C. de. Perspectivas para o reflorestamento no estado do Pará a partir do uso da terra no nordeste e sudeste paraense. Revista Amazônia: Ciência e Desenvolvimento, v.7, p. II3-I27, 2011.

ARAUJO, H. J. B. DE; MAGALHÃES, W. L. E.; OLIVEIRA, L. C. Durabilidade de madeira de eucalipto citriodora (Corymbia citriodora (Hook.) K.D. Hill \& L.A.S. Johnson) tratada com CCA em ambiente amazônico. Acta Amazônica, v.42, n. I, p. 49-58, 2012.

ARCO-VERDE, M. F; SCHWENGBER, D. R. Avaliação silvicultural de espécies florestais no estado de Roraima. Revista Acadêmica: Ciências Agrárias e Ambientais, v. I, n. 3, p. 59-63, 2003.

BAYER, C.; MIELNICZUK, J. Dinâmica e Função da Matéria Orgânica. In: SANTOS, J. A. Fundamentos da Matéria Orgânica do Solos: Ecossistemas Tropicais \& Subtropicais. Metrópole, 2008. p. 7-18.
BORGES, C. M. Resposta da comunidade de formigas ao corte seletivo e corredores de floresta nativa e a plantações de eucalipto em uma região da Amazônia Brasileira. 2011. 44p. Dissertação de Mestrado, Universidade Federal de Lavras, Lavras.

DEXTER, A. R. Soil physical quality. Part III. Unsaturated hydraulic conductivity and general conclusions about $\mathrm{S}$ theory. Geoderma, v. I20, n. 3-4, p. 227-239, 2004.

EMBRAPA. Manual de Métodos de Análise de Solo. 2.ed. EMBRAPA-Centro Nacional de Pesquisa de Solos, 1997. 2 I 2p.

FARIAS, J. DE; MARIMON, B. S.; SILVA, L. de C. R.; PETTER, F. A.; ANDRADE, F. R.; MORANDI, P. S.; MARIMONJUNIOR, B. H. Survival and growth of native Tachigali vulgaris and exotic Eucalyptus urophylla $\mathrm{x}$ Eucalyptus grandis trees in degraded soils with biochar amendment in southern Amazonia. Forest Ecology and Management, v. 368, p. 173-182, 2016.

GUARIZ, H. R.; PICOLI, M. H. S.; CAMPANHARO, W. A.; CECÍLIO, R. A. Variação da Umidade e da Densidade do Solo sob Diferentes Coberturas Vegetais. Revista Brasileira de Agroecologia, v. 4, n. 2, p. 3293-3296, 2009.

KOSTIAKOV, A. N. On The Dynamics of the Coefficient of Water Percolation in Soils and the Necessity for Studying It from a Dynamic Point of View for Purpose of Amelioration. Society of Soil Science, v. 14, p. I7-21, 1932.

MATOS, G. S. B.; SILVA, G. R. da; GAMA, M. A. P.; VALE, R. S. do; ROCHA, J. E. C. Desenvolvimento inicial e estado nutricional de clones de eucalipto no nordeste do Pará. Acta Amazonica, v. 42, n. 4, p. 49I-500, 2012.

MONCADA, M. P.; PENNING, L. H.; TIMM, L. C.; GABRIEL, D.; CORNELIS, W. M. Visual examinations and soil physical and hydraulic properties for assessing soil structural quality of soils with contrasting textures and land uses. Soil \& Tillage Research, v. I40,p. 20-28, 2014.

PEREIRA, A. L.; CAMPOS, M. C. C.; SOUZA, Z. M. de.; CAVALCANTE, I. H. L.; SILVA, V. A. da; MARTINS FILHO, M. V. Atributos do solo sob pastagem em sistema de sequeiro e irrigado. Ciência e Agrotecnologia, v.33, n. 2, p.377-384, 2009.

REICHERT, J. M.; REINERT, D. J.; BRAIDA, J. A. Qualidade dos solos e sustentabilidade de sistemas agrícolas. Ciência \& Ambiente, v. 27, p. 29-48, 2003.

REICHERT, J. M.; SUZUKI, L. E. A. S.; REINERT, D. J. Compactação do solo em sistemas agropecuários e florestais: identificação, efeitos, limites críticos mitigação. In: Tópicos em Ciência do Solo. Sociedade Brasileira de Ciência do Solo, 2007. p.49-134.

REICHERT, J. M.; KAISER, D. R.; REINERT, D. J.; RIQUELME, U. F. B. Variação temporal de propriedades físicas do solo e crescimento radicular de feijoeiro em quatro sistemas de manejo. Pesquisa Agropecuária Brasileira, v. 44, n. 93, p. 310-319, 2009. 
REYNOLDS, W. D.; BOWMAN, B. T.; DRURY, C. F; TAN. C. S.; LU, X. Indicators of good soil physical quality: density and storage parameters. Geoderma, v. I I0, n. I-2, p.|31I46, 2002.

SEPOF. Estatística Municipal. 20I4. Availableat:http:// fapespa2.pa.gov.br/pdf/estatisticaMunicipal/pdf/ Paragominas.pdf . Accessed in: 10 march 2014.

SILVA, G. R. da; SILVA JÚNIOR, M. L. da; MELO, V. S. de. Efeitos de diferentes usos da terra sobre as características químicas de um latossolo amarelo do Estado do Pará. Acta Amazônica, v.36, n. 2, p.15I-158, 2006.

SILVA, S. G. C.; SILVA, A. P.; GIAROLA, N. F. B.; TORMENA, C. A.; SÁ, J. C. de M. Temporary effect of chiseling on the compaction of a Rhodic Hapludox under no-tillage. Revista Brasileira de Ciência do Solo, v.36, n. 2, p. 547555, 2012.
TEIXEIRA, S. C. Eficiência de utilização de nutrientes, produção e fertilidade do solo de plantios de eucalipto em função do espaçamento, em Dom Eliseu, Pará. 2014. 74p. Dissertação Mestrado. Universidade Federal Rural da Amazônia, Belém, 2014.

TORRES, L. C.; BARROS, L. C.; BARROS, K. R. M.; LIMA, H. V. de. Alterações na qualidade física de um Latossolo Amarelo sob pastagem. Acta Amazônica, v.44, n. 4, p.419-426, 2014.

VAN GENUCHTEN, M. T. A closed-form equation for predicting the hydraulic condutivity of unsatured soil. Soil Science Society of America, v.44, p.892-898, 1980.

VIANA, M. B. O eucalipto e os efeitos ambientais do seu plantio em escala. Brasília: Consultoria Legislativa da Câmara dos Deputados, 2004. Available at: http:/ / bd.camara.gov.br/bd/handle/bdcamara/II62. Accessed in: 16 July 2016. 